\title{
Critical appraisal on the use of everolimus in renal transplantation as an immunosuppressant to prevent organ transplant rejection
}

This article was published in the following Dove Press journal:

Transplant Research and Risk Management

20 January 2010

Number of times this article has been viewed

\section{Fernando Giron \\ Yenny Baez}

Kidney Transplant Service, Colombiana de Trasplantes, Bogota, Colombia
Correspondence: Fernando Giron Scientific Director, Colombiana de Trasplantes, Calle 6I N I3-23 Oficina 402 Bogota, Colombia Tel +57 I 805। I 65

Fax +57 I 805।I64 Email fgiron@colombianadetrasplantes. com

\begin{abstract}
Everolimus is a proliferation inhibitor designed to target chronic allograft nephropathy including prevention of acute rejection. Acute renal allograft rejection incidence varies with the therapy used for immunosuppression. Registry data show that $15 \%$ to $35 \%$ of kidney recipients will undergo treatment for at least one episode of acute rejection within the first post-transplant year. Everolimus has been used as therapy with full- or reduced-dose cyclosporine A without evidence of increasing the acute rejection incidence. This review will summarize the available clinical trial data on the use of everolimus and its role in preventing acute rejection incidence in renal transplantation.
\end{abstract}

Keywords: calcineurin inhibitors, cyclosporine, everolimus, biopsy-proven acute rejection, renal transplantation, acute rejection

\section{Introduction}

With annual graft survival rates of more than $90 \%$ in the first year after a renal transplantation, the current clinical challenge is to develop immunosuppressive protocols to decrease the risk of losing the graft in the long term, while keeping the current low rates of biopsy-proven acute rejection (BPAR). ${ }^{1,2}$

Immunosuppressive therapy has improved considerably since the introduction of azathioprine in 1961. The incidence of acute rejection has decreased notably in the last decade thanks to the emergence of new immunosuppressive drugs like proliferation signal inhibitors (PSI).

The introduction of cyclosporine in the 1980s as part of immunosuppressive maintenance therapy in organ transplantation was a milestone in reducing the incidence of acute rejection during the first year after transplantation. ${ }^{3}$

Everolimus is a PSI that acts at a later stage of the cell cycle, blocking the proliferation signal provided by these growth factors and preventing cells from entering the $\mathrm{S}$ phase. ${ }^{4}$ It has been evaluated in four different immunosuppressive algorithms, as replacement of a calcineurin inhibitor (CNI) or of an antimetabolite, in combination with a CNI either in low or high dose and with variable doses of CNI.

Most of surrogate endpoints of graft survival usually favor the use of mTOR (low rejection risk and good renal function). .,6 $^{5}$

This review will summarize the clinical trial data for everolimus and its role in preventing acute rejection. 


\section{Everolimus vs mycophenolate mofetil with full-dose cyclosporine $\mathbf{A}$}

Two randomized studies of similar design on de novo renal transplantation evaluated the efficacy and safety of everolimus vs mycophenolate mofetil (MMF) over a 3-year period, with a dose of everolimus of $1.5 \mathrm{mg} /$ day, everolimus $3 \mathrm{mg} /$ day, or MMF $2 \mathrm{~g}$ /day associated with a full dose of cyclosporine A (CsA) microemulsion $\left(\mathrm{Neoral}^{\circledR}\right)$ and steroids. ${ }^{5,6}$ In both cases the primary objective was to compare the effect on incidence of failure in each treated group after 12 and 36 months. The results demonstrated that everolimus is equally effective as MMF in terms of acute rejection 3 years post transplantation. ${ }^{5,6}$ The risk of BPAR was 3.4 times greater for patients with everolimus levels lower than $3 \mathrm{ng} / \mathrm{mL}$ compared with those with levels of 3 to $8 \mathrm{ng} / \mathrm{mL}(P<0.0001)$. A meaningful difference between the treatment arms was noted in study B251, in which the incidence of antibody-treated acute rejection was significantly lower in patients taking everolimus $1.5 \mathrm{mg}$ /day than patients taking MMF at 12 months $(7.8 \%$ vs $16.3 \% P=0.01)$ and at 36 months of follow-up (9.8\% vs $18.4 \%$, respectively; $P=0.014){ }^{6}$

\section{Everolimus combined with full- or reduced-dose CsA}

Data obtained from both the Vitko and Lorber studies showed that everolimus and full-dose CsA could improve renal function without increasing acute rejection incidence. ${ }^{5,6}$ A randomized, phase II, open-label, 3-year study in 111 patients compared the efficacy and tolerability of everolimus ( $3 \mathrm{mg} /$ day) in combination with basiliximab, steroids, and either full-dose Neoral (FDN) vs reduced-dose Neoral (RDN) (CsA trough levels [C0] 125 to $250 \mathrm{ng} / \mathrm{mL}$ and 50 to $100 \mathrm{ng} / \mathrm{mL}$, respectively). ${ }^{7}$ Efficacy failure (BPAR, death, graft loss, or loss to follow-up) were evaluated at 6,12 , and 36 months.

BPAR incidence was less frequent in the RDN group than in the FDN group at every point of the follow-up (6 months: $3.4 \%$ vs $15.1 \%$; 12 months, $6.9 \%$ vs $17 \%$; and 36 months, $12.1 \%$ vs $18.9 \%$, respectively). BPAR episodes were mild or moderate. This study therefore demonstrated the utility of the combination of everolimus and reduced-dose CsA, since it improved renal function without changing BPAR incidence. ${ }^{7}$

Based on these data, two multicenter, randomized controlled studies, 2306 and 2307, were designed to compare 12-month efficacy and safety of everolimus 1.5 and $3 \mathrm{mg} /$ day with reduced-dose CsA guided by C2 monitoring and corticosteroids in de novo renal transplant recipients at 12 months. ${ }^{8,9}$ The only difference was that the 2307 had induction with basiliximab on days 0 and 4 . When the study was limited to nonblack patients, study 2306 showed a lower incidence of acute rejection with $3 \mathrm{mg} /$ day (16.4\%) compared with $1.5 \mathrm{mg} /$ day $(25.9 \%)(P=0.08)$. In study 2307 , the inclusion of basiliximab lowered the overall incidence of acute rejection; $14.3 \%$ with $3 \mathrm{mg} /$ day and $13.6 \%$ with $1.5 \mathrm{mg} /$ day at 12 months $(P=0.891)$. The use of an inductor agent like basiliximab reduces the risk of acute rejection combined with a low dose of everolimus and a reduced dose of Neoral..$^{8,9}$

In both studies, BPAR was more common in patients with average levels $<3 \mathrm{ng} / \mathrm{mL}$ compared to those with levels $>3 \mathrm{ng} / \mathrm{dL}$. A Cox regression model demonstrated that the risk of BPAR was affected by the exposure to everolimus, a relationship that was significant in study 2307 $(P=0.001){ }^{8,9}$

\section{Everolimus with full- and reduced- dose tacrolimus}

Although most of the studies with everolimus have been made in combination with cyclosporine, few data are available on the use of everolimus with tacrolimus.

Chang, in a prospective, multicenter, open-label, exploratory, randomized 6-month study in de novo renal transplant patients that evaluated the efficacy and safety of everolimus, steroids and basiliximab in combination with a reduced or full dose of tacrolimus, showed that BPAR incidence was $14 \%$ in each cohort (not significant). ${ }^{9}$ All cases of BPAR were mild (Banff IA or IB). However, although this is considered to be a low incidence of acute rejection, additional studies are warranted because of the small differences in tacrolimus exposure in the two arms. ${ }^{10}$

\section{Ongoing phase III-IV studies with everolimus}

The use of everolimus in kidney transplantation is being studied in several phase III-IV clinical studies. The studies with BPAR as one of their outcomes are shown in Table 1. Some additional studies with partial results are described and discussed below.

\section{EVEREST (The upper target EVErolimus RandomizEd Study)}

This a phase III, 6-month randomized, multicenter, open-label study, designed to investigate whether increased everolimus exposure ( $\mathrm{UEVL}$ ) in combination with very low $\mathrm{CsA}$ is effective for preventing BPAR compared to standard 
Table I Summary of clinical studies of everolimus and acute rejection

\begin{tabular}{|c|c|c|c|c|}
\hline References & Design & Study length & Treatments & Patients (n) \\
\hline 18 & $\begin{array}{l}\text { Phase III, multicenter, randomized, } \\
\text { parallel group, open-label }\end{array}$ & 2 years & $\begin{array}{l}\text { Everolimus } 1.5 \mathrm{mg} / \text { day or everolimus } \\
3 \mathrm{mg} / \text { day + dose reduced CsA vs EC-MPS + } \\
\text { standard dose CsA }\end{array}$ & 833 de novo \\
\hline 19 & $\begin{array}{l}\text { Phase IV, multicenter, randomized, } \\
\text { open label, parallel group }\end{array}$ & I year & $\begin{array}{l}\text { Everolimus and basiliximab in combination } \\
\text { with CsA, either discontinued after } 3 \text { month } \\
\text { or minimized }\end{array}$ & 119 de novo \\
\hline 20 & $\begin{array}{l}\text { Phase IV, multicenter, randomized, } \\
\text { open-label, parallel group }\end{array}$ & I year & $\begin{array}{l}\text { Basiliximab + EC-MPS + CsA + steroids, } \\
\text { randomized to } 3 \text { groups } \\
\text { I. Everolimus + steroids (CNI stopping) } \\
\text { 2. Everolimus + CsA (steroids stopping) } \\
\text { 3. EC-MPS + CsA + steroids (control group) }\end{array}$ & I77 de novo \\
\hline 21 & $\begin{array}{l}\text { Phase IV, multicenter, randomized, } \\
\text { open label-parallel group }\end{array}$ & I year & $\begin{array}{l}\text { Everolimus + basiliximab and steroids, in a } \\
\text { maintained vs discontinued CsA regimen }\end{array}$ & 51 de novo \\
\hline 22 & $\begin{array}{l}\text { Phase IV, multicenter, } \\
\text { randomized, open label }\end{array}$ & I year & $\begin{array}{l}\text { basiliximab }+ \text { everolimus }+ \text { Tac }+ \text { steroids for } \\
3 \text { months, further randomized to: } \\
\text { I. Everolimus }+ \text { Tac very low dose } \\
\text { 2. Everolimus }+ \text { Tac low dose }\end{array}$ & 230 de novo \\
\hline 23 & $\begin{array}{l}\text { Phase III, prospective, multicenter, } \\
\text { randomized, open-label, parallel group }\end{array}$ & I year & $\begin{array}{l}\text { Everolimus in combination with low dose } \\
\mathrm{CNI} \text { free vs EC-MPS with standard dose CNI }\end{array}$ & 450 de novo \\
\hline 24 & $\begin{array}{l}\text { Phase IIIb-IV, prospective, } \\
\text { multicenter, randomized, } \\
\text { open label, parallel group }\end{array}$ & 2 years & $\begin{array}{l}\text { Patients in maintenance with } \mathrm{CNI} \pm \mathrm{EC}-\mathrm{MPS} / \\
\mathrm{AZA} \pm \text { steroids } \text {, further randomized to: } \\
\text { I. Keep same treatment with } \mathrm{CNI} \\
\text { 2. Everolimus + stopping } \mathrm{CNI} \\
\text { 3. Everolimus + reduction } \mathrm{CNI} \\
\text { MPA/AZA and the steroids dose is kept } \\
\text { in all the groups. }\end{array}$ & 398 maintenance \\
\hline
\end{tabular}

Abbreviations: CsA, cyclosporine; CNI, calcineurin inhibitor; EC-MPS, enteric-coated mycophenolate sodium; MPA, mycophenolic acid; AZA, azathioprine; Tac, tacrolimus.

exposure (sEVL). ${ }^{11}$ All patients received basiliximab induction and steroids and were further randomized to:

- Everolimus high dose (8 to $12 \mathrm{ng} / \mathrm{mL}$ ) and very-low-dose CsA (C2 $600 \mathrm{ng} / \mathrm{mL}$ reduced to $300 \mathrm{ng} / \mathrm{mL}$ at 3 months).

- Everolimus standard dose ( 3 to $8 \mathrm{ng} / \mathrm{mL}$ ) and low-dose CsA (C2 $600 \mathrm{ng} / \mathrm{mL}$ reduced to $500 \mathrm{ng} / \mathrm{mL}$ at the third month).

After 12 months, the incidence of BPAR with high levels of everolimus was $14.9 \%$ vs $15 \%$ with standard levels (not significant). In conclusion, everolimus in combination with low-dose CsA or very-low-dose CsA is effective in preventing BPAR and is well tolerated. ${ }^{12}$

\section{CALLISTO}

This is a 12-month, phase III, multicenter, randomized, open-label study in 139 de novo renal transplant patients at risk of developing delayed graft function (DGF), designed to compare immediate vs delayed everolimus treatment. All patients received basiliximab and steroids and were randomized to everolimus $(1.5 \mathrm{mg} /$ day $)$ immediately post transplant from day 1 (IE) or after 4 weeks of mycophenolic acid treatment (DE) in combination with CsA. ${ }^{13}$
BPAR composite was one of the primary endpoints. Results at 12 months showed that BPAR was $20 \%$ in the group with immediate everolimus vs $20.3 \%$ in the group with delayed everolimus $(P=1.00)$. In conclusion, the time to start everolimus in patients with risk of developing DGF does not affect the incidence of BPAR. ${ }^{14}$

\section{ZEUS}

This study has been conducted in de novo renal transplant patients to investigate efficacy and safety of everolimus/ enteric-coated mycophenolate sodium (EC-MPS) regimen after CNI withdrawal. ${ }^{15}$ After induction therapy with basiliximab, all patients were treated with CsA, EC-MPS, and corticosteroids for the first 4.5 months post transplant. Subsequently, patients were randomized 1:1 to either continue the current regimen of CsA and EC-MPS or to change from CsA to everolimus. The primary objective of this trial was to show superiority of a CNI-free regimen with respect to the renal function at 12 months post transplant as assessed by glomerular filtration rate (Nankivell method) compared with the standard CNI-based regimen. It has 300 patients. 
The BPAR in the follow-up of the first 147 patients was $16.3 \%$ in the everolimus/EC-MPS group vs $12.9 \%$ in the CsA/ECMPS group. These results show that in this group of patients the conversion from CsA to everolimus is safe. ${ }^{16}$

Currently, the follow-up of all patients in this study was completed at 12 months $(n=300)$ at which time the BPAR was $14.8 \%$ for the everolimus/EC-MPS group vs $15.2 \%$ for the CsA/EC-MPS group. This finding confirms that the introduction of everolimus/EC-MPS in de novo renal transplant patients alters CNI withdrawal and offers a novel therapeutic approach which significantly affects renal function without compromising efficacy and safety. ${ }^{17}$

\section{Conclusions}

Several clinical trials have shown the efficacy and tolerability of everolimus. The results have shown that everolimus is as effective as MMF in preventing acute rejection. Preliminary clinical trial results (EVEREST, CALLISTO, and ZEUS) indicate that the use of everolimus in combination with CNI minimization/withdrawal is safe as part of maintenance immunosuppressant therapy in renal transplant patients, and the incidence of BPAR is similar to that with other immunosuppression protocols; however, it should be noted that these results have been obtained in association with the use of an induction agent (basiliximab). Ongoing clinical studies will provide further information about the effectiveness of everolimus to prevent renal transplant rejection.

\section{Acknowledgments}

The author would like to thank Edgar Ospina, who provided medical writing support on behalf of Novartis Pharma AG.

\section{Disclosures}

The authors declare no conflicts of interest.

\section{References}

1. Meier-Kriesche HU, Schold JD, Srinivas TR, Kaplan B. Lack of improvement in renal allograft survival despite a marked decrease in acute rejection rates over the most recent era. Am J Transplant. 2004;4:378-383.
2. Giron F, Baez Y, Niño-Murcia A, Rodriguez J, Salcedo S. Conversion therapy to everolimus in renal transplant recipients: Results after one year. Transplant Proc. 2008;40:711-713.

3. Morris P. Kidney Transplantation. 5th edition. 2001;227-242.

4. Pascual J, Boletis IN, Campistol JM. Everolimus (Certican) in renal transplantation: a review of clinical trial data, currente usage, and future directions. Transplant Rev. 2006;20:1-18.

5. Vitko S, Margreiter R, Weimar W, et al.Three-year efficacy ans safety results from a study of everolimus versus mycophenolate mofetil in de novo renal transplant patients. Am J Transplant. 2005;5:2521-2530.

6. Lorber MI, Mulganonkar S, Butt KM, et al. Everolimus versus mycophenolate mofetil in the prevention of rejection in de novo renal transplant recipients: a 3-year randomized, multicenter, Phase III study. Transplantation. 2005;80:244-252.

7. Nashan B, Curtis J, Ponticelli C, et al. Everolimus and reduced-exposure cyclosporine in de novo renal-transplant recipients: a three-year phase II, randomized, multicenter, open-label study. Transplantation. 2004; 78:1332-1340.

8. Vitko S, Tedesco H, Eris J, et al. Everolimus with optimized cyclosporine dosing in renal transplant recipients: 6-month safety and efficacy results of two randomized studies. Am J Transplant. 2004;4:624-635.

9. Tedesco Silva H Jr, Vitko S, Pascual J, et al. 12-month safety and efficacy of everolimus with redued exposure cyclosporine in de novo renal transplant recipients. Transpl Int. 2007;20:27-36.

10. Chan L, Greenstein S, Hardy MA, et al. Multicenter, randomized study of the use of everolimus with tacrolimus after renal transplantation demonstrates its effectiveness. Transplantation 2008;85:821-826.

11. EVEREST. ClinicalTrials.gov. Accessed 1 September 2009.

12. Salvadori M, Scolari M, Bertoni E, et al. Upper everolimus blood levels with very low dose cyclosporin: 12 months follow up of the Everest Study. [abstract] American Transplant Congress; 2009.

13. CALLISTO. Clinicaltrials.gov. Accessed 1 September 2009.

14. Dantal J, Berthoux F, Moal MC, et al. Immediate vs delayed everolimus treatment in de novo renal transplant patients at risk of delayed graft function: Results. American Transplant Congress; 2009.

15. ZEUS. ClinicalTrials.gov. Accessed 1 September 2009.

16. Bude K, Klempnauer J, Arns W, et al. Renal function, efficacy and safety of everolims (RAD)/Enteric-Coated Mycophenolate sodium (EC-MPS) therapy after calcineurin inhibitor (CNI) withdrawal in de novo renal transplant patients: Final outcomes of the ZEUS STUDY. Transplantation. 2008;86 Suppl 2:S93.

17. Reinke P, Arns W, Becker Y, et al. Efficacy and safety of an everolimus/ enteric-coated Mycophenolate sodium regimen after calcineurin inibitor withdrawal in de novo renal transplant patients: Results of the ZEUS trial. European Society for Organ Transplantation; 2009.

18. Study A2309. ClinicalTrials.gov. Accessed 1 September 2009.

19. Study A2419. ClinicalTrials.gov. Accessed 1 September 2009.

20. Steroid Or Cyclosporine Removal After Transplantation using Everolimus (SOCRATES) study (A2421). ClinicalTrials.gov. Accessed 1 September 2009.

21. Study A2423. ClinicalTrials.gov. Accessed 1 September 2009.

22. Study A2426. ClinicalTrials.gov. Accessed 1 September 2009.

23. HERAKLES Study. ClinicalTrials.gov. Accessed 1 September 2009.

24. ASsessment of Everolimus in Addition to Calcineurin Inhibitor Reduction in the Maintenance of Renal Transplant Recipients (ASCERTAIN) study (A2413). ClinicalTrials.gov. Accessed 1 September 2009.
Transplant Research and Risk Management

\section{Publish your work in this journal}

Transplant Research and Risk Management is an international, peerreviewed open access journal focusing on all aspects of transplantation and risk management to achieve optimal outcomes in the recipient improving survival and quality of life. The journal welcomes submitted papers covering original research, basic science, clinical studies,

\section{Dovepress}

reviews \& evaluations, guidelines, expert opinion and commentary, case reports and extended reports. The manuscript management system is completely online and includes a very quick and fair peer-review system, which is all easy to use. Visit http://www.dovepress.com/ testimonials.php to read real quotes from published authors. 